\title{
Expansive Visibilization to Stimulate EFL Teacher Reflection
}

Ryu Ito

Despite the growing popularity of action research, bridging the gap between data collection and reflective data analysis still lacks a well-developed methodology. As a supplement to the traditional action research procedure for language teaching, I adopted a method called expansive visibilization (EV), which has the potential to be a reflective stimulus that facilitates the reflection of action researchers. EV was originally proposed by Engeström (1999a) to help workers better understand and improve their workplace activities. I describe two EV sessions. The participants were two college and high school EFL teachers in Japan. Each went through the crucial second stage of EV. The participants first explained the daily contradictions that they faced when teaching. Subsequently, I asked them to draw a triangular diagram of their teaching and explain their teaching again using the diagram. I compared their explanations before and after use of the diagram. EV seemed to have changed the nature of the first participant's reflection, but not that of the second. This contrast demonstrates both the feasibility and limitations of $E V$ as a supplement to conventional action research.

Malgré la popularité croissante de la recherche-action, il n'existe toujours pas de méthodologie bien développée pour faire le pont entre la cueillette de données et l'analyse de données réflexives. Pour enrichir la procédure traditionnelle en recherche-action dans le cadre de l'enseignement de langues, j'ai adopté une méthode qui s'appelle la "visibilisation expansive», et qui a le potentiel d'agir comme stimulus pour faciliter la réflexion des chercheurs. Cette méthode a d'abord été proposée par Engeström pour aider les travailleurs à mieux comprendre les activités qu'ils pratiquent dans leur milieu de travail et à les améliorer. Je décris deux sessions de visibilisation expansive. Deux enseignants d'ALE aux niveaux collégial et secondaire au Japon ont participé à l'étude et ont passé la deuxième étape cruciale de la visibilisation expansive. Les participants ont commencé par expliquer les contradictions quotidiennes auxquelles ils faisaient face quand ils enseignaient. Par la suite, je leur ai demandé de dessiner un diagramme triangulaire pour représenter leur enseignement et ensuite d'expliquer de nouveau leur pratique en y faisant référence. Par la suite, j'ai comparé l'explication qu'ils avaient donnée avant de dessiner le diagramme à celle qu'ils ont fournie après. La visibilisation expansive semble avoir changé la nature de la réflexion du premier participant, mais pas celle du deuxième. Ce contraste illustre à la fois les possibilités et les limites de l'emploi de la visibilisation expansive comme supplément à la recherche-action classique. 
A wide range of approaches fall into the category of qualitative research. Action research has been one of the most commonly used qualitative approaches in studies of language teaching. ${ }^{1}$ This study introduces expansive visibilization (EV, Engeström, 1999a) as a potential supplement to the traditional action research procedure that stimulates teachers to reflect on their practice. The feasibility of EV is explored by presenting two cases.

Action research is usually adopted in the paradigm of critical theory, one of the influential paradigms in social and human sciences. Critical discourse analysis (Kumaravadivelu, 1999; Luke, 2002; Norton, 1997; O' Halloran, 2007), critical ethnography (Canagarajah, 1993; May, 1997; Toohey, 1995), and critical pedagogical approach (Goldstein, 1997; Pennycook, 1994, 1994b, 2001) also fall into the critical theory paradigm. In this paradigm, research is a change-oriented intervention (van Lier, 2004). It is thus "ultimately concerned with action" (Edge \& Richards, 1998, p. 341). This means that teachers doing action research are more interested in understanding and solving problems in their teaching than in generalizing knowledge (Nunan, 1992). Crookes (2005) perceives this critical perspective as "an essential spark in action research" (p. 470 ). Because of the nature of the critical theory paradigm, reliability and validity in the traditional positivistic sense are not considered goals of action research. Instead, the quality of action research is usually evaluated by the willingness of teachers as researchers to act on suggestions derived from their research results (Greenwood \& Levin, 2005).

This relativist tendency has been criticized by positivist scholars for lacking a distinctive methodology. Although I do not advocate rigid standardization in action research, which can damage its flexibility and openness, I believe that we should not tolerate what Engeström (1999b, p. 35) calls "naïve forms of action research," where spontaneous ideas coming from teachers are idealized. Despite the long tradition of action research in pedagogy, there are limited studies on its methodology (Burns, 2005). A book by Kemmis and McTaggart (1988), regarded as a classic in action research methodology (Crookes, 2005), outlines four stages in research: planning, acting, observing, and reflecting. In the planning stage, teachers as action researchers collect data from their teaching. Based on the data, they reflect on their teaching, recognize problems with it, and create an action plan to improve their practice. Studies on action research have paid little attention to the methodology used to bridge the gap between data-collection and reflective data-analysis in this initial stage.

Many authors on action research regard teachers' reflective analysis as an automatic process (Winter, 1989). It is relatively straightforward for teachers to accumulate and describe the data that they collect, but this process does not directly lead to reflective data-analysis (Borg, 2003; Griffiths \& Tann, 1992). Consequently, they tend to continue their routine practice without being aware of what actually happens in class. Even when they recognize 
some problems in their teaching, it is natural for them to resist change (Clarke, 2003). Introspection of oneself and one's work is sometimes rigorous and painful (Birch, 1992; Lazaraton \& Ishihara, 2005; Stanley, 1998). In this study, I introduce EV (Engeström, 1999a) as a promising stimulus that encourages teachers as action researchers to reflect on their collected data in the initial stage of action research.

EV was originally proposed by Engeström (1999a) for workers to analyze and improve their workplace activities. The term expansive signifies an approach in which the linear dimension of work actions are seen in the broader perspective of multidimensional work activity; the term visibilization, coined by Engeström, describes deliberate attempts to make work visible and understandable. EV has its theoretical grounds in Cultural-Historical Activity Theory (CHAT). Activity theory is sometimes regarded as a category of sociocultural theory (Mitchell \& Myles, 2004). Sociocultural theory has stimulated many studies in language education, for example, on the zone of proximal development (ZPD, Adair-Hauck \& Donato, 1994; Aljaafreh \& Lantolf, 1994; Ohta, 2000a; Washburn, 1994) and inner/private speech (de Guerrero, 1994; McCafferty, 1992, 1994a, 1994b; Ohta, 2000b; Ushakova, 1994). However, activity theory has not attracted as much attention as sociocultural theory. Some researchers in the field of language education have touched on activity theory (Ahmed, 1994; Coughlan \& Duff, 1994; Donato, 2000; Donato \& McCormick, 1994; Gillette, 1994; Gutiérrez, 2008; Lantolf, 2000a, 2000b; Lantolf \& Appel, 1994; Lantolf \& Pavlenko, 1995; Nassaji \& Wells, 2000; Pavlenko \& Lantolf, 2000; Roebuck, 2000; van Lier, 2000), but only a limited number have explored it in detail (Ito, 2000; Lantolf \& Genung, 2002; Lantolf \& Pavlenko, 2001; Lantolf \& Thorne, 2006; Ochs, 2002; Thorne, 2004, 2005; van Lier, 2004). $\mathrm{EV}$, which is theoretically supported by CHAT, is quite relevant to this unexplored field.

In this article, I first discuss the potential of $\mathrm{EV}$ as a reflective stimulus in action research. Second, I consider a historical view of the development of CHAT to explicate the theoretical background that supports the use of EV. Third, I elaborate on the procedure of EV. Last, I present two cases that demonstrate the second stage of EV to explore its feasibility as a supplement to action research.

\section{EV as Reflective Stimulus in Action Research}

The methodology for reflective data analysis in the initial stage of action research is underdeveloped. However, some methods that have been introduced in studies on reflective language teaching (Farrell, 2007; Richards, 1991; Richards \& Lockhart, 1996) and on teacher development in general (Brock, Yu, \& Wong, 1992; Mann, 2005; Richards, 1992; Richards \& Farrell, 2005) show the potential to be adopted to stimulate teachers' reflection. These methods include journal-writing, lesson reports, critical-incident analysis, 
teaching portfolios, and concept-mapping. Among these, concept-mapping is rarely used as a stimulus for language teachers' reflection (Borg, 2006), but it is distinctive for using diagrams as a reflective stimulus. In concept-mapping, teachers are expected to construct a hierarchical cobweb-shaped graphical representation of their knowledge of teaching (Farrell).

Cognitive scientists have studied the merits of using diagrams as cognitive stimuli. Norman (1993) states that human memory, thought, and reasoning are highly constrained without external aids and that the real powers of the human mind lie in devising external aids that enhance its cognitive ability. The diagram that is constructed in concept-mapping is one example of an external aid. Such aids help the human mind to simplify complex events and grasp them, and they can be tools for social communication. Several people can reflect on the same event at the same time with the assistance of external aids. In principle, high-order thought can be stimulated without external aids; however, as Norman indicates, "In practice, the limited ability to keep track of things in active consciousness severely reduces that possibility" (p. 51).

The superiority of diagrams as stimuli over verbal descriptions is also asserted in studies on human problem-solving. In the seminal paper "Why a diagram is (sometimes) worth ten thousand words," Larkin and Simon (1987) conclude that "diagrams can group together all information that is used together, thus avoiding large amounts of search for the elements needed to make a problem-solving inference" (p. 98). In contrast, information in a list of verbal descriptions is sometimes visually separated, and identifying it requires considerable patient searching (Koedinger \& Anderson, 1990).

Although the advantages of diagrams over verbal descriptions have been investigated in studies on human cognition and problem-solving, there is little discussion of the potential of diagrams as communication stimuli between researchers and participants (Crilly, Clarkson, \& Blackwell, 2006; Törrönen, 2002). Among a limited number of studies, Crilly et al. indicate that diagrams differ from other communication stimuli in terms of ambiguity: "In some instances, diagrams permit very vague depictions yet still remain coherent, while in other instances they demand the concrete representation of an uncertain situation" (p. 361). Using a graphical stimulus can also facilitate rapport between researchers and participants, which provides richer and more nuanced data, especially for sensitive issues (Kesby, 2000). If we consider that it is sometimes awkward and even threatening for teachers to discuss their own class, school, colleagues, and students (Birch, 1992), diagrams can be a promising reflective stimulus.

The form of EV that I introduce in this article uses diagrams as reflective stimuli in the communication between teachers as action researchers and collaborators. The difference between concept-mapping and EV resides in the scope of their graphical representation. In concept-mapping, teachers as re- 
searchers can expand the scope of their diagrams as much as they wish. If they reflect not only on micro factors in the classroom but also on macro factors about school, community, and government, the scope of diagrams expands accordingly. However, when their reflection is limited to their classroom, the scope of diagrams also becomes limited. Furthermore, the wide discretion left to the person who draws a map makes it difficult to compare the maps. Unlike concept-mapping, the diagrams employed in EV include macro factors from the outset, which encourages teachers to broaden their reflection. The construction of diagrams in EV coincides with the literature of language-teacher education, which emphasizes the necessity to address issues that transcend the classroom and to consider institutional, cultural, political, and historical influences (Burns, 2005; Johnson, 2006; Melles, 2001). The unlimited extension of the diagram that is characteristic of concept-mapping is not allowed in EV; thus the diagrams are more easily contrasted with one another. The following section explores the historical development of CHAT and the concrete stages of $\mathrm{EV}$.

\section{EV Based on CHAT}

\section{Historical Development of CHAT}

A triangular diagram plays a crucial role in EV. The central part of this diagram was invented by a pioneer of CHAT, developed by his successors, and completed by present-day CHAT scholars; the historical development of CHAT is mirrored in the constructs of the diagram. Thus tracing the history of CHAT is necessary to understand the diagram used in EV. Engeström (2001) provided an overview that traces the origin of CHAT to the works of Vygotsky (1896-1934) in the 1920s. He proposed the idea of mediation to interpret higher forms of human action. A human action, the basic unit of analysis in his theory, is expressed as a three-part model of subject, object, and artifacts (Vygotsky, 1978). ${ }^{2}$ The subject is the protagonist in the analysis, and the object is "the 'raw material' or 'problem space' at which the activity is directed" (Engeström, 1993, p. 67). The artifacts signify the tool that humans use for successful completion of activities. In his explanation of mediating artifacts, Vygotsky includes not only physical tools such as pens and machines, but also psychological tools such as language, concepts, and decisionmaking procedures. This wide and multilayered range of artifacts distinguishes humans from other species (Wartofsky, 1979).

A standard representation of teaching based on Vygotsky's (1978) perspectives could be as expressed in Figure 1. For success, the subject requires the coordination of two routes to the object (Cole, 1996). To help learners (object) learn successfully, the teacher (subject) is required to coordinate both the route that goes directly to the learners and the route that goes to the learners via tools such as a textbook, task, test, and computer (artifacts). The 


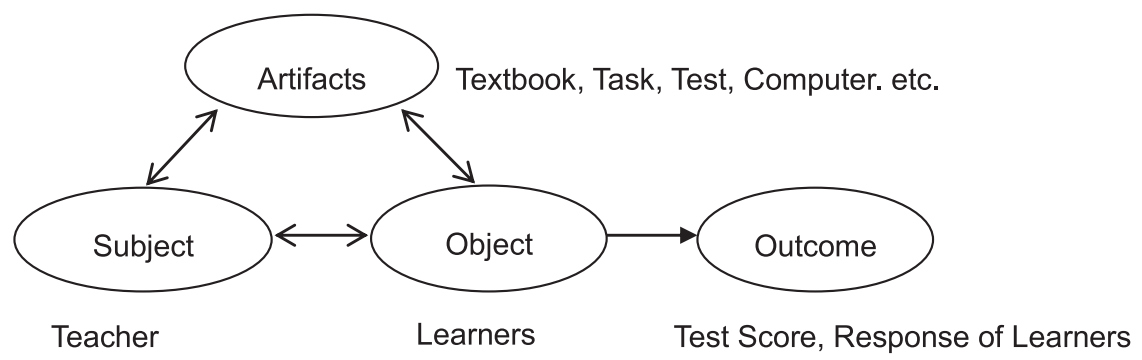

Figure 1. Standard representation of teaching based on Vygotsky's model.

teacher needs to perceive the learners through the lens of the artifacts without diminishing the effort toward direct access to the learners. According to Vygotsky, teaching can be considered as the teachers' coordination among learners, various teaching tools, and themselves.

One of Vygotsky's (Daniels, 2001) most important achievements was showing that human actions could not be understood sufficiently without considering mediating artifacts. However, Vygotsky tended to focus on individuals because he did not live long enough to explain how human actions that are mediated by artifacts are linked to specific cultural and historical settings (Wertsch, 1991). Consequently, he did not fully conceptualize the collaborative nature of human actions (Engeström, 1996). Thus the theory developed by Vygotsky is sometimes criticized for not fully considering the role of macrolevel factors such as community and society (Watson-Gegeo, 2004).

This limitation was overcome by Alexei Leontyev (1903-1979), who differentiated the concepts of activity and action (Daniels, 2001) and considered the relationship between an individual and a community. Leontyev (1981) stated, "The product of the process as a whole, which meets the need of the group, also leads to satisfaction of the needs of the separate individual as well" (p. 210). He indicated that division of labor distinguishes collective activity from individual action. He also differentiated between cultural-historical factors and inter-subject factors; these two sets of factors have often been confused in studies claiming to deal with factors beyond the individual level of analysis (Daniels, 2001). However, Leontyev did not graphically expand Vygotsky's model (Engeström, 2001).

Engeström (1948-) and Cole (1938-) accomplished the graphical expansion. Engeström called their school of thought CHAT and distinguished it from other branches of activity theory. To Vygotsky's original triad model, which consisted of subject, object, and artifacts, Engeström (1991) added 
three new constructs: rules, community, and division of labor. Rules are norms and conventions that constrain actions. Community refers to those who share the same object. Division of labor is "the division of object-oriented actions among members of the community" (Cole, 1996, p. 141). These three new constructs can be situated under "Subject" and "Object" in Figure 1 as "the less visible social mediators of activity" (Engeström, 1994, p. 45), representing the contributions of this generation of CHAT researchers. Russell (1997) indicates that a rigid distinction between the classroom micro-level and the contextual macro-level may be overcome by including these three additional constructs in the analysis.

Engeström (1994) presented a standard image of teaching. In this model, a teacher (subject) uses tools such as a textbook, task, test, and computer (artifacts) to teach learners (object). This teaching activity is performed in cooperation with other teachers in the same and other classes. These teachers constitute a group (community), follow curricula and syllabi (rules), and usually share the teaching activity in school by conducting lessons in self-contained classrooms (division of labor). The activity continually reconstructs itself, as do the contents of each of the six constructs above. For example, the object is not a stationary target because the subject defines the object in various ways depending on the type of problem the object faces (Engeström, 1995). ${ }^{3}$ The object can be "learners with difficulty in increasing fluency in EFL speaking" or "learners who confuse the present and past tenses in ESL writing." Engeström's model of human activity plays a crucial role in the procedure for using EV, which I examine below.

\section{Stages of EV}

Engeström (1999a) divides EV into four stages. The first is data-collection in the field, that is, a teacher gathers information about the class. The second stage is a unique feature of EV: a teacher and a research collaborator ${ }^{4}$ model the teacher's activities using the triangular diagram presented by Engeström. The collaborator can be a researcher, colleague, or supervisor. The collaborator does not necessarily require an extensive background and training, but rather a sympathetic attitude toward the teacher's process of reflection and articulation. The diagram is not a rigid explanatory model, but a heuristic template to inspire the teacher's reflection on his or her teaching. Using this diagram, the teacher and collaborator are expected to articulate latent problems, conflicts, or disturbances in teaching, which in EV parlance are called contradictions (Engeström). However, contradictions are not always obvious. Schön (1983), who proposed the concept of reflection-in-action, indicated that contradictions must be constructed from puzzling, troubling, and uncertain situations. According to Engeström (2001), contradictions do not always have negative implications, but can be an innovative force in the field. If contradictions are not identified, it is considered impossible for practitioners to im- 
prove their practice. This assertion reflects a basic tenet of Engeström's CHAT, that is, that the specification of contradictions and the limitation of long-established customs are important aspects of development. Therefore, it is essential for the teacher and the collaborator to think critically about the teacher's teaching and to bring contradictions to light with the help of the diagram. It is also significant for them during this second stage to have tentative conceptualizations of the future when contradictions are either resolved or left untouched. These two possible outcomes are respectively called expanded activity and contracted activity (Engeström, 1999a). At the end of the second stage, the teacher and the collaborator formulate a specific action plan to realize an expanded activity.

In the third stage, the teacher and collaborator implement the action plan set out at the end of the second stage and attempt to change the current target teaching activity to an expanded activity. The results of the third stage are examined critically in the fourth stage. In action research on language-teaching supplemented by EV, the teacher and the collaborator need to check both intended and unintended practical outcomes such as the test scores and survey results of learners. They may also revert to the first stage and prepare a new action plan to improve teaching further if required. EV, as well as action research, is a cyclical and repetitive process that continually seeks out selfimprovement.

Both EV and action research fall within the critical theory paradigm, and thus their research procedures appear analogous. Consequently, those who conduct action research can adopt the distinctive second stage of EV in their research procedure. Because of the scarcity of studies on how to bridge the gap between data-collection and reflective data analysis in terms of action

Traditional Action Research
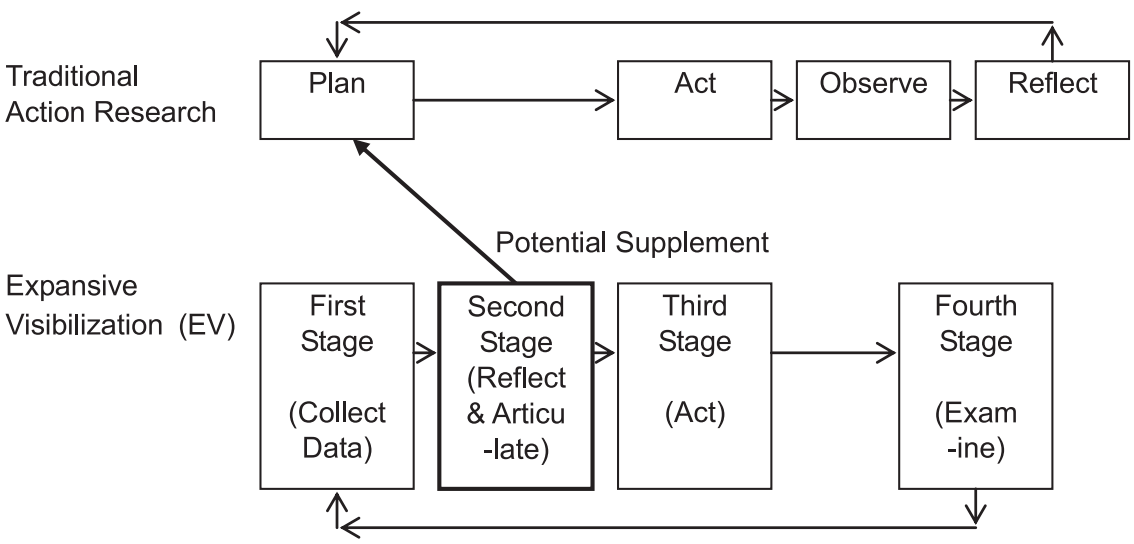

Figure 2. Procedural correspondence between traditional action research and expansive visibilization (EV). 
research methodology, the second stage in EV has unique potential as a supplement to the action research procedure. A procedural correspondence between traditional action research and EV is illustrated in Figure 2.

\section{Case Studies of EV}

The sections below present two cases of the second and essential stage of EV, that is, reflecting on the teachers' teaching through the construction of a triangular diagram. EV seems to have changed the nature of a teachers' reflection in the first case, but not in the second. These illustrations aim to explore the feasibility of the second stage of EV as a supplement to the traditional action research procedure for language teaching.

\section{Participants}

The participants were two EFL teachers working in Japan. In Japan, over 95\% of students who have completed nine years of compulsory education attend three-year high schools or five-year technical colleges. Over $97 \%$ of high school students graduate, and nearly half of the graduates enter two- or fouryear programs in colleges or universities. The first participant (P1) was a Japanese man working in a public college in an urban area. Approximately $99 \%$ of his students were Japanese in their late teens or early 20 s. They were not majoring in English and had not necessarily acquired advanced EFL proficiency. However, the college designated EFL as a compulsory course for all students because it is considered useful for international business. P1 had a master's degree in TESOL and had studied for a year in a graduate school in the United Kingdom. Before this EV session, he had worked for four years in his first full-time job as an assistant professor in the college.

The second participant (P2) was a Japanese woman working in a public high school in an urban area. All her students were Japanese between 16 and 18 years of age. All students at her school were required to take EFL classes. Considering that more than $95 \%$ of graduates from this school attended university each year, their EFL proficiency was higher than that of an average Japanese high school student. P2 had a master's degree in TESOL and became a teacher in this school immediately after graduation. Before this EV session, she had worked in the school for eight years in her first full-time job. Both teachers were professional acquaintances of mine (for over 10 years each) and were assured that their identities would remain confidential. Confidentiality was ensured in accordance with the guidelines for maintaining trust in research using interviewing techniques (Fontana \& Frey, 2005).

\section{Procedures}

Because Engeström's study did not specify how to communicate with participants in EV, I needed to develop his procedure. Although I acknowledge that communication between a teacher as an action researcher and a collab- 
orator is more like a conversation than an interview, I referred to studies on interviewing because it has a long history of polishing the methodology. Interviews vary along a continuum from structured to semistructured to unstructured (Johnson, 1992). Noting its potential for rich interaction with participants and avoidance of unnecessary control over them, I adopted the techniques of the semistructured interview, which has attracted widespread interest in qualitative research (Flick, 2009). Nunan (1992) defines semistructured interviews as follows: "The interviewer has a general idea of where he or she wants the interview to go, and what should come out of it, but does not enter the interview with a list of predetermined questions" (p. 149).

All my conversations with the participants were in Japanese to ensure maximum mutual understanding. However, I did not translate English labels that appeared in the visual diagram that I used to explain Engeström's model. As a collaborator, I first asked the participants about any contradictions that they faced in class or elsewhere in school. I raised this question to ascertain the range of contradictions that they could grasp without the help of EV. The question was deliberately vague because I wanted them to consider it from several perspectives. After presenting Engeström's model as a template of the triad diagram, I asked them to modify the template to match their current teaching practices. Then I asked them to explain their diagram to determine whether using the diagram changed their reflections on the contradictions that they faced. To ascertain whether their reflections were profound enough to bring about any resolution to their contradictions, I asked them to modify their own teaching diagrams into diagrams of an expanded future activity in which their contradictions would be resolved.

After a 40-minute EV session with each teacher, I transcribed the recordings and analyzed the remarks made by the teachers at three points: at the beginning of EV, after they had constructed the triangular diagram, and after they had built the diagram of an expanded activity. Because the teachers and I communicated in Japanese, the translation of the transcripts into English might have distorted the teachers' original meaning. Instead of including translated transcripts, I chose to summarize teachers' comments by meaning condensation, which is defined as "an abridgement of the meanings expressed by the interviewees into shorter formulations" (Kvale, 1996, p. 192). Thus this article presents only the gist of the teachers' reflections. ${ }^{5}$ The subjectivity of researchers is not necessarily problematic in the critical theory paradigm; however, when condensing the transcripts, I strove to exclude biased subjectivity, which signifies researchers' selective attention only to the evidence that justifies their own conclusions (Kvale). To minimize the possibility of bias and maximize reflexive elaboration, I later presented my interpretations of the transcripts and triangular diagrams to the teachers for their verification and feedback. This process is called respondent validation (Silverman, 2006; Willig, 2008), communicative validation (Flick, 2009; Steinke, 2004), or member check (McLeod, 2001). 


\section{Findings}

Before starting EV, P1 pointed out two contradictions that he faced in school. First, he noted that each EFL teacher in his college had his or her own implicit teaching objectives. In fact it was not necessarily common for teachers to present teaching objectives explicitly in Japanese colleges. As a result, P1 felt that their EFL teaching did not always meet students' long-range needs. Second, teachers in his college encouraged students to take the TOEIC exam, a business-English-language proficiency test for non-native speakers administered by the Educational Testing Service. However, there was no clear policy to relate the test to the curriculum and students' ultimate needs after graduation. Because P1 could not think of any more contradictions, I suggested that he consider other viewpoints, and in response to my cue, he pointed out another contradiction. Students in the higher grades could not take additional EFL courses because the curriculum of the college required them to pursue specialized courses related to their major. He regarded this as a reason for the deterioration of some students' EFL proficiency.

I asked P1 to construct a diagram of his teaching based on Engeström's model, and he made three modifications (Figure 3) to the original diagram. First, he expanded the construct of community by adding "teachers at secondary schools" to the original "other teachers at the school." He believed that students were still strongly influenced by their past learning experiences

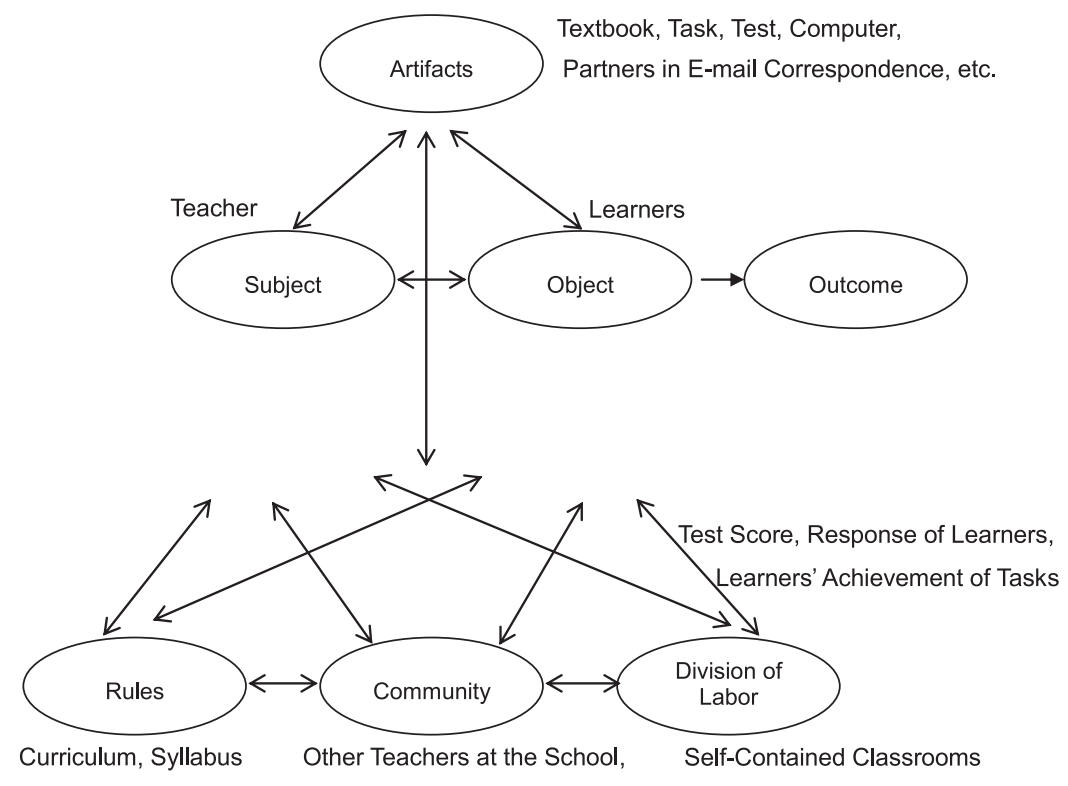

Figure 3. P1's image of current teaching practices. 
with secondary schoolteachers even though those teachers were not at his college. He gave an example of the difficulty of introducing learning tasks in secondary school that require active participation from students who are accustomed to a passive learning style. He also mentioned that Japanese cultural and societal tendencies might have an influence on some secondary schoolteachers. As an example, he cited expectations for students to sit in silence and regard rote memorization as an efficient means of learning.

Second, he added "partners in e-mail correspondence" to the construct of artifacts. He used the Internet in a computer-equipped classroom in the college, giving his students the task of corresponding by e-mail with nativeEnglish-speaking students at partner schools. According to the original definition of artifacts by Engeström, this was not an appropriate categorization, and I deliberated whether to correct him. In the end, I did not mention this issue, because the diagram is not a rigid explanatory model, but a heuristic template to stimulate teachers' reflection. In the critical theory paradigm, the potential for insights that could lead to improvement in teaching outweighs the value of a strictly accurate interpretation of the original model. P1 subsequently reported that using the Internet in class had both positive and negative effects because computers on students' desks could sometimes cause distractions.

Third, he considered "learners' achievement of tasks" an important aspect of outcomes and added it to the construct of outcome. I reminded P1 that he could pay attention to triadic connections in the diagram such as the relationships among subject, rules, and community. In response, he said that some other teachers at his college also recognized shortcomings in the curriculum, but that it was not easy for them to resolve these problems due to disagreements about how to improve the program. ${ }^{6}$

P1 subsequently constructed a diagram of an expanded activity where contradictions would be resolved (Figure 4). He added features to each of the three constructs in the bottom row of the triangular diagram. First, he added "needs analysis" beside the construct of rules and indicated that it was necessary for EFL teachers at the college to be more interested in both the needs of students after graduation and the demands of the EFL curriculum by other teachers. Second, he expanded the construct of community by adding "technical staff and part-time teachers" and "teachers at the partner school using e-mail correspondence." Third, he added "other teachers' involvement in class" to the construct of division of labor. He explained that he did not intend to criticize the current division of self-contained classrooms, but emphasized the need to work in closer cooperation with those in the community beyond the boundaries of the classroom. He further noted that this cooperation would help students who needed advice on studying EFL and would reduce the contradiction of the college's curriculum that prohibited students in higher grades from taking additional EFL courses. 


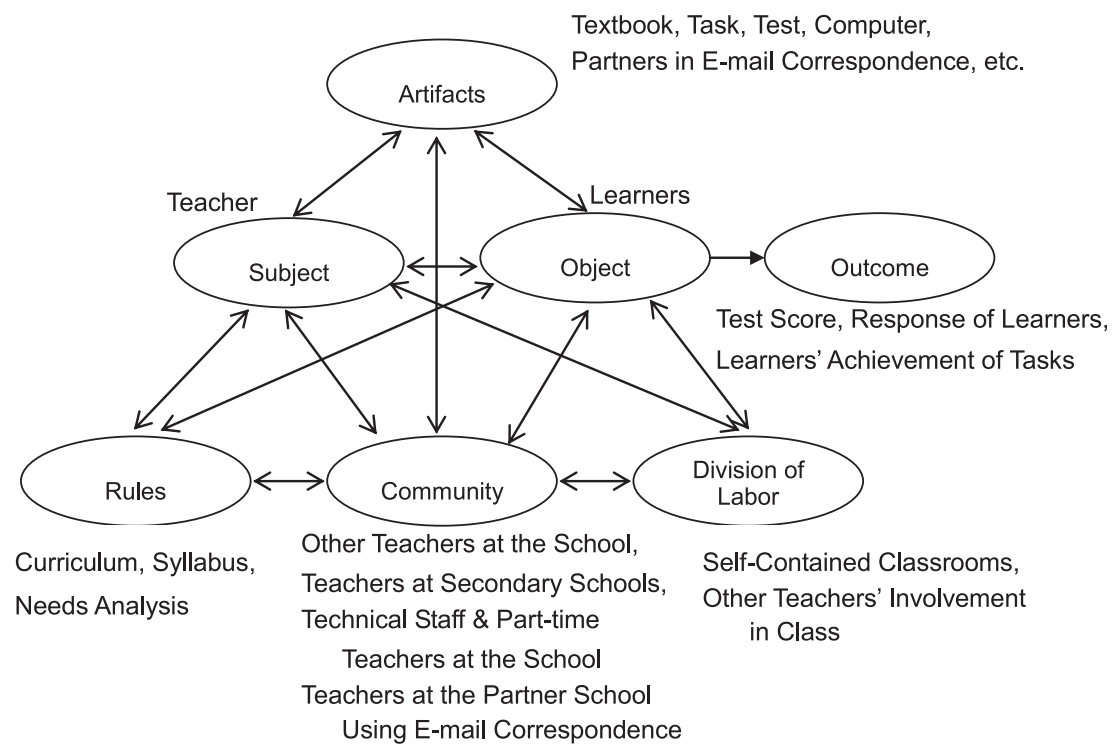

Figure 4. P1's image of expanded teaching practices.

I also asked P2 about the contradictions that she faced in school, and she pointed out two. First, she hesitated to impose many listening and speaking tasks in regular classes because these two skills were not necessary to pass college or university entrance examinations. Although acknowledging that entrance exams motivated her students to learn EFL, she recognized the importance of tackling a variety of learning tasks. Second, she was too busy with trivial everyday chores to prepare adequately for her classes and noted that this was a chronic problem for many teachers at her school.

I asked P2 to modify Engeström's model to correspond to her teaching, and she made four modifications to the original diagram. First, she expanded the construct of artifacts by adding "assistants who are native speakers of English," "visiting teachers from other schools," and "guest students from other countries," all of whom occasionally joined her class. She explained that these people could have been included in the construct of community, but because they had a more direct influence on her classroom practices than the traditional constituents in the construct of community, it was more suitable for her to include them in the construct of artifacts. I realized that we had deviated from Engeström's original definition of artifacts, but I prioritized facilitating the natural flow of P2's reflection as I had in the session with P1. She also divided "test" in the original diagram into tests within the school and those created by organizations outside the school. Second, she added "learners' parents and relatives," "cram schools," "other high schools," and 
"people in the town" to the construct of community. Third, she identified "university entrance exam" as a hidden curriculum and added it to the construct of rules. Fourth, in addition to the original factors in the construct of outcome, she included "learners' sense of achievement," "change or establishment of learners' learning style," and "results of the university entrance exam."

P2 subsequently constructed a diagram of an expanded activity where contradictions would be resolved. She focused her attention on the construct of outcome and added "evaluation based on more elaborate needs analysis." Although admitting that the results of the university entrance exam could be an index of the outcomes of her teaching, she hoped to adopt an alternative student evaluation system that would consider the occupational needs of students after graduation. She mentioned that to establish this evaluation system, an elaborate needs analysis of Japanese high school students was indispensable. The topic of conversation then spontaneously shifted to the importance of basing teaching objectives on a sophisticated needs analysis. However, she did not make any additions to the diagram.

\section{Implications}

By using the diagram, both participants elaborated on their reflections about their teaching, but their reflections varied substantially. The diagram seemed to arouse P1's reflection, whereas P2 may not have fully taken advantage of the diagram. For example, by reflecting on the contents in the construct of artifacts in his current teaching, P1 came up with "partners in e-mail correspondence" as an important factor mediating between himself and his students. It is technically incorrect to place this concept in the construct of artifacts, but through this modification of the diagram, P1 identified another contradiction that computers on students' desks could cause distractions. P1's explanation of his teaching not only became more detailed, but also broadened in scope throughout the process of constructing the diagram. The three contradictions that $\mathrm{P} 1$ articulated before constructing the diagram can be interpreted as problems related to curriculum development in the college, all of which are in the construct of rules. While constructing the diagram of his current teaching, however, he started to perceive his teaching from another viewpoint. He indicated that it was difficult to introduce learning tasks that required students' active participation. He attributed this problem to the students' learning experiences in secondary school, a historical cause, and to cultural and societal causes characteristic of Japan that considerably influenced secondary school teaching and learning styles. Consideration of triad relationships among the constructs of the diagram also affected P1's reflections. With regard to the three contradictions about curriculum development that he had already recognized, P1 elaborated on their latent causes by considering the relationship among subject, rules, and community in the diagram. Thus paying attention to a triangular relationship in the diagram 
during EV helped P1 consider potential causes for the contradictions. Whereas P1 pointed out three more contradictions during the explanation for the diagram of his current teaching, P2 made no explicit mention of contradictions. However, P2 cannot be regarded as less involved in reflection than P1. P2's reflections about her teaching with the help of the diagram were substantially different from those of P1. Before using the diagram, P2 supplemented the original diagram with 11 more factors to explain her teaching, and P1 added three factors. This gap might be attributed to differences in cultural influences on the two participants. P2, who had less overseas experience than P1, might have been more influenced by a Japanese communication norm that complaining openly is an indication of a speaker's immaturity. P2's lack of reference to contradictions may also be attributed to an institutional difference and the collaborator's understanding. That is, P2 was a secondary school teacher, but P1 and I both work in higher education; therefore, I had more empathy with P1's work than with P2's. Consequently, P2 had had to exert greater effort to explain her teaching to me. This may have focused her attention more on explanations than on expression of contradictions.

The difference in reflection about contradictions between the two participants becomes more remarkable if one compares their utterances about contradictions at the beginning of EV and when they were constructing the diagram of an expanded activity. P1 concentrated his attention only on issues in the construct of rules at the beginning of the session, but when considering the expanded activity, his focus widened, and he started to talk about the relationships among constructs. Before constructing the diagram of the expanded activity, he focused on the triangular relationships in the diagram. It was not certain whether he was actually aware of these relationships, but in his explanation of the expanded activity, few of his comments focused on only one construct in the diagram. The shift in focus by P1 was not an unnatural phenomenon. It fits what Block (2000) wrote about participants in interviewing research: "The same research participants might change voices depending on the way they situate themselves vis-à-vis a particular question and the person asking it" (p. 760). This is an indication of EV stimulating P1's reflections, which might be difficult to be aroused immediately in regular discussions or interviews. However, the diagram of an expanded activity did not seem to evoke P2's reflection on contradictions. It is true that her remarks changed slightly, but considering that she seldom took advantage of the diagram to explain contradictions, it is not likely that the diagram of an expanded activity accounts for this change.

These two cases reveal both the feasibility and the limitations of EV as a supplement to action research on language-teaching. Feasibility was encapsulated in the remarks that P1 made at the end of the EV session. He told me that the session had provided him with a different perspective on his teaching and clarified his previously blurred picture of it. His articulation of the con- 
tradictions, which in a non-research context might be seen as a fruitless complaint, brought about potential solutions. His utterances and diagrams indicated that through the process of EV, his reflections became more detailed and extended in scope to historical, cultural, and societal causes of contradictions.

However, P2 showed me that EV is limited in certain circumstances. When a teacher as an action researcher considers a critical attitude shameful or when a collaborator possesses little preliminary knowledge of the teacher's work, the collaborator needs to play a more active role. While refraining from providing leading questions and verbal or nonverbal responses that may serve as positive or negative reinforcers, the collaborator must repeatedly encourage the teacher to focus on the triangular relationships in the diagram and to verbalize contradictions. Without this support from the collaborator, EV might not differ a great deal from traditional action research, which operates without the triangular diagram.

To stimulate teachers' reflection, the layout of the triad diagram may require modification. At the end of the EV session, P1 advised me to move the three constructs in the bottom row to the upper row so that the research participants could direct more attention to factors that are usually hidden. In the light of P1's suggestion, it seems possible that the pyramidal shape of the existing diagram could bias reflection because the position of artifacts at the apex may make them appear more important.

\section{Concluding Remarks}

Although action research is expected to contribute to the empowerment of teachers (Edge, 2001), the role of language-teachers in generating knowledge through reflection has not been generally recognized (Crandall, 2000). The centrality of teachers at the second stage of EV has the potential to empower them continually to play a prominent role in the rest of the action research procedure (see Figure 2 for the entire procedure). However, it could be daunting for busy teachers to complete all stages of action research supplemented by EV. Borg (2009) indicates that although there are many inspiring examples, research is still a minority activity among English teachers. This might be caused by the time-consuming procedure of action research. In this case, teachers can attempt only the second, but core stage of EV that I illustrate in this article. Borg (2010) asserted that problem-solving, which is often regarded as a central tenet of action research, is not always required. This claim aligns with exploratory practice (Allwright, 2005), which is a more feasible form of teacher research. Although problem-solving for the teaching practice is a long-range goal in action research, the efforts merely to understand their current practice is also useful for teachers' professional development.

The latent difficulties in putting EV into practice need attention. First, the scope of teachers' reflection can expand through EV, as illustrated in the first case, but there is a risk that one may overlook aspects other than the seven 
constructs in the diagram. EV can overcome this drawback and become a more powerful tool for action research if used with other research methods, especially those for micro-analysis such as conversation and interaction analyses. Second, some teachers maintain a fixed view of what teaching should be, which is likely to be an obstacle to reflection (Hatton \& Smith, 1995; Yost, Sentner, \& Forlenza-Bailey, 2000). When teachers resist from the outset any thinking about how they need to modify their teaching, EV does not yield fruitful insights. Therefore, it may be necessary for a teacher and a collaborator to clarify and agree on the aim of the EV session before they start it. Third, there is a possibility that school administrators or colleagues may interfere with action research activities (Bailey, Curtis, \& Nunan, 2001). Some may worry that research extending beyond the boundaries of their own classrooms will reveal defects and threaten their professional standing. Finally, evaluative methods for qualitative research are still controversial (Eisner, 1997; Flick, 2009; Rogers, 2000). The difficulty of assessing qualitative research by traditional positivist criteria reduces the likelihood that conservative stakeholders such as educational policymakers and school boards will accept the insights of such research (Bell, 2002; Johnson, 2006). When key stakeholders reject qualitative research out of hand, neither time nor financial support will officially be set aside for teachers to reflect (van Lier, 1996). Teachers who adopt EV as a supplement to their action research must not only continue to refine the research methodology to establish solid theoretical ground, but also develop a means to evaluate critically their research outcome.

\section{Notes}

${ }^{1}$ Although the context of the two cases presented in this article is that of EFL (English as a foreign language) teaching, I believe that EV is useful for foreign- and second-language teaching in general. In this article, language teaching is a generic term for activities to teach foreign and second languages.

${ }^{2}$ Vygotsky (1978) originally used the term stimulus to signify subject and the term response to denote object.

${ }^{3}$ Engeström (1995) enumerates three types of problems: frequent and straightforward, rare and complex, and frequent but complex. Although these problems are drawn from research in health centers, they can also be applied to educational settings.

${ }^{4}$ Traditional action research does not require a collaborator, so teachers as action researchers can proceed unaided. However, many studies on action research methodology note the significance of collaboration, because without collaboration, reflection and articulation are usually restricted to an individual's unshared subjective effort (Burns, 1999; Edge, 2001, 2002; Melles, 2001; Roberts, 1998; Wallace, 1998). Johnson (1999) indicated that teachers who discussed their teaching in a collaborative setting better understood their thoughts about teaching and their teaching skills. This suggests that when action researchers supplement their research procedure with EV, it is desirable to have a collaborator.

${ }^{5} \mathrm{My}$ aim is not to criticize the inclusion of translated transcripts in research papers per se. Presentation of transcripts is essential in conversation analysis, which has achieved considerable significance in language-teaching research.

${ }^{6}$ In many colleges in Japan, teachers have autonomy over their classes, which can hinder their collaboration in reforming the curriculum. 


\section{Acknowledgments}

I thank Miyuki Sasaki, Yoshiyuki Notohara, and Junko Hayashi for their valuable suggestions and encouragement, and two anonymous research participants for their generous collaboration. The opinions expressed and any errors in this article are solely my responsibility.

\section{The Author}

Ryu Ito is an associate professor in the Faculty of Economics at Nagoya Gakuin University, Japan. He has studied research methodologies of applied linguistics, language teachers' cognition, and the sociocultural analysis of classroom activities.

\section{References}

Adair-Hauck, B., \& Donato, R. (1994). Foreign language explanations within the zone of proximal development. Canadian Modern Language Review, 50, 532-557.

Ahmed, M.K. (1994). Speaking as cognitive regulation: A Vygotskian perspective on dialogic communication. In J.P. Lantolf \& G. Appel (Eds.), Vygotskian approaches to second language research (pp. 157-171). Norwood, NJ: Ablex.

Aljaafreh, A., \& Lantolf, J.P. (1994). Negative feedback as regulation and second language learning in the zone of proximal development. Modern Language Journal, 78, 465-483.

Allwright, D. (2005). Developing principles for practitioner research: The case of exploratory practice. Modern Language Journal, 89, 353-366.

Bailey, K.M., Curtis, A., \& Nunan, D. (2001). Pursuing professional development: The self as source. Boston, MA: Heinle \& Heinle.

Bell, J.S. (2002). Narrative inquiry: More than just telling stories. TESOL Quarterly, 36, 207-213.

Birch, G.J. (1992). Language learning case study approach to second language teacher education. In J. Flowerdew, M. Brock, \& S. Hsia (Eds.), Perspectives on second language teacher education (pp. 283-294). Kowloon: City Polytechnic of Hong Kong.

Block, D. (2000). Problematizing interview data: Voices in the mind's machine? TESOL Quarterly, 34, 757-763.

Borg, S. (2003). Teachers' involvement in TESOL research. TESOL Matters, 13(2), 1-8.

Borg, S. (2006). Teacher cognition and language education: Research and practice. London: Continuum.

Borg, S. (2009). English language teachers' conceptions of research. Applied Linguistics, 30, 358-388.

Borg, S. (2010). Language teacher research engagement. Language Teaching, 43(4), 391-429.

Brock, M.N., Yu, B., \& Wong, M. (1992). "Journaling" together: Collaborative diary-keeping and teacher development. In J. Flowerdew, M. Brock, \& S. Hsia (Eds.), Perspectives on second language teacher education (pp. 295-307). Kowloon: City Polytechnic of Hong Kong.

Burns, A. (1999). Collaborative action research for English language teachers. Cambridge, UK: Cambridge University Press.

Burns, A. (2005). Action research: An evolving paradigm? Language Teaching, 38(2), 57-74.

Canagarajah, A.S. (1993). Critical ethnography of a Sri Lankan classroom: Ambiguities in student opposition to reproduction through ESOL. TESOL Quarterly, 27, 601-626.

Clarke, M.A. (2003). A place to stand: Essays for educators in troubled times. Ann Arbor, MI: University of Michigan Press.

Cole, M. (1996). Cultural psychology: A once and future discipline. Cambridge, MA: Belknap Press of Harvard University.

Coughlan, P., \& Duff, P.A. (1994). Same task, different activities: Analysis of a SLA task from an activity theory perspective. In J.P. Lantolf \& G. Appel (Eds.), Vygotskian approaches to second language research (pp. 173-193). Norwood, NJ: Ablex. 
Crandall, J. (2000). Language teacher education. Annual Review of Applied Linguistics, 20, 34-55.

Crilly, N., Clarkson, P.J., \& Blackwell, A.F. (2006). Using research diagrams for member validation in qualitative research. In D. Barker-Plummer, R. Cox, \& N. Swoboda (Eds.), Diagrammatic representation and inference: 4th international conference, Diagram 2006 Stanford, CA, USA, June 2006 proceedings (pp. 258-262). Berlin: Springer.

Crookes, G. (2005). Resources for incorporating action research as critique into applied linguistics graduate education. Modern Language Journal, 89, 467-475.

Daniels, H. (2001). Vygotsky and pedagogy. London: Routledge Falmer.

de Guerrero, M.C.M. (1994). Form and functions of inner speech in adult second language learning. In J.P. Lantolf \& G. Appel (Eds.), Vygotskian approaches to second language research (pp. 83-115). Norwood, NJ: Ablex.

Donato, R. (2000). Sociocultural contributions to understanding the foreign and second language classroom. In J.P. Lantolf (Ed.), Sociocultural theory and second language learning (pp. 27-50). Oxford, UK: Oxford University Press.

Donato, R., \& McCormick, D. (1994). A sociocultural perspective on language learning strategies: The role of mediation. Modern Language Journal, 78, 453-464.

Edge, J. (2001). Attitude and access: Building a new teaching/learning community in TESOL. In J. Edge (Ed.), Action research (pp. 1-11). Alexandria, VA: Teachers of English to Speakers of Other Languages.

Edge, J., \& Richards, K. (1998). May I see your warrant, please? Justifying outcomes in qualitative research. Applied Linguistics, 19, 334-356.

Eisner, E.W. (1997). The new frontier in qualitative research methodology. Qualitative Inquiry, 3, 259-273.

Engeström, Y. (1991). Developmental work research: A paradigm in practice. Quarterly Newsletter of the Laboratory of Comparative Human Cognition, 13(4), 79-80.

Engeström, Y. (1993). Developmental studies of work as a testbench of activity theory: The case of primary care medical practice. In S. Chaiklin \& J. Lave (Eds.), Understanding practice: Perspectives on activity and context (pp. 64-103). Cambridge, UK: Cambridge University Press.

Engeström, Y. (1994). Teachers as collaborative thinkers: Activity-theoretical study of an innovative teacher team. In I. Carlgren, G. Handal, \& S. Vaage (Eds.), Teachers' minds and actions: Research on teachers' thinking and practice (pp. 43-61). London: Falmer.

Engeström, Y. (1995). Objects, contradictions and collaboration in medical cognition: An activity-theoretical perspective. Artificial Intelligence in Medicine, 7, 395-412.

Engeström, Y. (1996). Development as breaking away and opening up: A challenge to Vygotsky and Piaget. Swiss Journal of Psychology, 55(2-3), 126-132.

Engeström, Y. (1999a). Expansive visibilization of work: An activity-theoretical perspective. Computer Supported Cooperative Work, 8, 63-93.

Engeström, Y. (1999b). Activity theory and individual and social transformation. In Y. Engeström, R. Miettinen, \& R. Punamaki (Eds.), Perspectives on activity theory (pp. 19-38). Cambridge, UK: Cambridge University Press.

Engeström, Y. (2001). Expansive learning at work: Toward an activity theoretical reconceptualization. Journal of Education and Work, 14(1), 133-156.

Farrell, T.S.C. (2007). Reflective language teaching: From research to practice. London: Continuum.

Flick, U. (2009). An introduction to qualitative research (4th ed.). London: Sage.

Fontana, A., \& Frey, J.H. (2005). The interview: From neutral stance to political involvement. In N.K. Denzin \& Y.S. Lincoln (Eds.), The Sage handbook of qualitative research (3rd ed., pp. 695-727). Thousand Oaks, CA: Sage.

Gillette, B. (1994). The role of learner goals in L2 success. In J.P. Lantolf \& G. Appel (Eds.), Vygotskian approaches to second language research (pp. 195-213). Norwood, NJ: Ablex. 
Goldstein, T. (1997). Language research methods and critical pedagogy. In N.H. Hornberger \& D. Corson (Eds.), Encyclopedia of language and education, Vol. 8: Research methods in language and education (pp. 67-77). Dordrecht, Netherlands: Kluwer.

Greenwood, D.J., \& Levin, M. (2005). Reform of the social sciences, and of universities through action research. In N.K. Denzin \& Y.S. Lincoln (Eds.), The Sage handbook of qualitative research (3rd ed., pp. 43-64). Thousand Oaks, CA: Sage.

Griffiths, M., \& Tann, S. (1992). Using reflective practice to link personal and public theories. Journal of Education for Teaching, 18(1), 69-84.

Gutiérrez, A.G. (2008). Microgenesis, method and object: A study of collaborative activity in a Spanish as a foreign language classroom. Applied Linguistics, 29(1), 120-148.

Hatton, N., \& Smith, D. (1995). Reflection in teacher education: Towards definition and implementation. Teaching and Teacher Education, 11(1), 33-49

Ito, R. (2000). Bunka rekishiteki katsudou riron to konpyuta riyou no gaikokugo kyouiku [Cultural-historical activity theory and computer-utilized foreign language education]. Casele Research Bulletin, 30, 95-103.

Johnson, D.M. (1992). Approaches to research in second language learning. New York: Longman.

Johnson, K.E. (1999). Understanding language teaching: Reasoning in action. Boston, MA: Heinle \& Heinle.

Johnson, K.E. (2006). The sociocultural turn and its challenges for second language teacher education. TESOL Quarterly, 40, 235-257.

Kemmis, S., \& McTaggart, R. (1988). The action research planner (3rd ed.). Victoria, Australia: Deakin University Press.

Kesby, M. (2000). Participatory diagramming as a means to improve communication about sex in rural Zimbabwe: A pilot study. Social Science and Medicine, 50, 1723-1741.

Koedinger, K.R., \& Anderson, J.R. (1990). Abstract planning and perceptual chunks: Elements of expertise in geometry. Cognitive Science, 14, 511-550.

Kumaravadivelu, B. (1999). Critical classroom discourse analysis. TESOL Quarterly, 33, 453-484.

Kvale, S. (1996). Interviews: An introduction to qualitative research interviewing. Thousand Oaks, CA: Sage.

Lantolf, J.P. (2000a). Second language learning as a mediated process. Language Teaching, 33(2), 79-96.

Lantolf, J.P. (2000b). Sociocultural theory and second language learning. Oxford, UK: Oxford University Press.

Lantolf, J.P., \& Appel, G. (1994). Vygotskian approaches to second language research. Norwood, NJ: Ablex.

Lantolf, J.P., \& Genung, P.B. (2002). “I'd rather switch than fight:" An activity-theoretic study of power, success, and failure in a foreign language classroom. In C. Kramsch (Ed.), Language acquisition and language socialization: Ecological perspectives (pp. 175-196). London: Continuum.

Lantolf, J.P., \& Pavlenko, A. (1995). Sociocultural theory and second language acquisition. Annual Review of Applied Linguistics, 15, 108-124.

Lantolf, J.P., \& Pavlenko, A. (2001). (S)econd (L)anguage (A)ctivity theory: Understanding second language learners as people. In M.P. Breen (Ed.), Learner contributions to language learning: New directions in research (pp. 141-158). Harlow, UK: Pearson Education.

Lantolf, J.P., \& Thorne, S. (2006). Sociocultural theory and the genesis of second language development. Oxford, UK: Oxford University Press.

Larkin, J.H., \& Simon, H.A. (1987). Why a diagram is (sometimes) worth ten thousand words. Cognitive Science, 11(1), 65-100.

Lazaraton, A., \& Ishihara, N. (2005). Understanding second language teacher practice using microanalysis and self-reflection: A collaborative case study. Modern Language Journal, 89, 529-542. 
Leontyev, A.N. (1981). Problems of the development of the mind. Moscow: Progress.

Luke, A. (2002). Beyond science and ideology critique: Developments in critical discourse analysis. Annual Review of Applied Linguistics, 22, 96-110.

Mann, S. (2005). The language teacher's development. Language Teaching, 38(3), 103-118.

May, S.A. (1997). Critical ethnography. In N.H. Hornberger \& D. Corson (Eds.), Encyclopedia of language and education, Vol. 8: Research methods in language and education (pp. 197-206). Dordrecht, Netherlands: Kluwer.

McCafferty, S G. (1992). The use of private speech by adult second language learners: A crosscultural study. Modern Language Journal, 76, 179-189.

McCafferty, S.G. (1994a). Adult second language learners' use of private speech: A review of studies. Modern Language Journal, 78, 421-436.

McCafferty, S.G. (1994b). The use of private speech by adult ESL learners at different levels of proficiency. In J.P. Lantolf \& G. Appel (Eds.), Vygotskian approaches to second language research (pp. 117-134). Norwood, NJ: Ablex.

McLeod, J. (2001). Qualitative research in counselling and psychotherapy. London: Sage.

Melles, G. (2001). In search of individual, group, and institutional coherence: Does this compute? In J. Edge (Ed.), Action research (pp. 145-157). Alexandria, VA: TESOL.

Mitchell, R., \& Myles, F. (2004). Second language learning theories (2nd ed.). London: Arnold.

Nassaji, H., \& Wells, G. (2000). What's the use of "triadic dialogue"? An investigation of teacher-student interaction. Applied Linguistics, 21, 376-406.

Norman, D.A. (1993). Things that make us smart: Defending human attributes in the age of the machine. Cambridge, MA: Perseus Books.

Norton, B. (1997). Critical discourse research. In N.H. Hornberger \& D. Corson (Eds.), Encyclopedia of language and education, Vol. 8: Research methods in language and education (pp. 207-216). Dordrecht, Netherlands: Kluwer.

Nunan, D. (1992). Research methods in language learning. Cambridge, UK: Cambridge University Press.

Ochs, E. (2002). Becoming a speaker of culture. In C. Kramsch (Ed.), Language acquisition and language socialization: Ecological perspectives (pp. 99-120). London: Continuum.

Ohta, A.S. (2000a). Rethinking interaction in SLA: Developmentally appropriate assistance in the zone of proximal development and the acquisition of L2 grammar. In J.P. Lantolf (Ed.), Sociocultural theory and second language learning (pp. 51-78). Oxford, UK: Oxford University Press.

Ohta, A.S. (2000b). Rethinking recasts: A learner-centered examination of corrective feedback in the Japanese language classroom. In J.K. Hall \& LS. Verplaetse (Eds.), Second and foreign language learning through classroom interaction (pp. 47-71). Mahwah, NJ: Erlbaum.

Pavlenko, A., \& Lantolf, J.P. (2000). Second language learning as participation and the (re)construction of selves. In J.P. Lantolf (Ed.), Sociocultural theory and second language learning (pp. 155-177). Oxford, UK: Oxford University Press.

Pennycook, A. (1994). Critical pedagogical approaches to research. TESOL Quarterly, 28, 690-692.

Richards, J.C. (1991). Towards reflective teaching. Teacher Trainer, 5(3), 4-8.

Richards, J.C., \& Farrell, T.S.C. (2005). Professional development for language teachers: Strategies for teacher learning. Cambridge, UK: Cambridge University Press.

Richards, K. (1992). Pepys into a TEFL course. ELT Journal, 46, 144-152.

Richards, J.C. \& Lockhart, C. 1996: Reflective teaching in second language classrooms. Cambridge, UK: Cambridge University Press.

Roberts, J. (1998). Language teacher education. London: Arnold.

Roebuck, R. (2000). Subjects speak out: How learners position themselves in a psycholinguistic task. In J.P. Lantolf (Ed.), Sociocultural theory and second language learning (pp. 79-95). Oxford, UK: Oxford University Press.

Rogers, A.G. (2000). When methods matter: Qualitative research issues in psychology. Harvard Educational Review, 70(1), 75-85. 
Russell, D.R. (1997). Rethinking genre in school and society: An activity theory analysis. Written Communication, 14, 504-554.

Schön, D.A. (1983). The reflective practitioner: How professionals think in action. New York: Basic Books.

Silverman, D. (2006). Interpreting qualitative data: Methods for analyzing talk, text and interaction (3rd ed.). London: Sage.

Stanley, C. (1998). A framework for teacher reflectivity. TESOL Quarterly, 32, 584-591.

Steinke, I. (2004). Quality criteria in qualitative research (B. Jenner, Trans.). In U. Flick, E. von Kardoff, \& I. Steinke (Eds.), A companion to qualitative research (pp. 184-190). London: Sage.

Thorne, S.L. (2004). Cultural historical activity theory and the object of innovation. In O. St. John, K. van Esch, \& E. Schalkwijk (Eds.), New insights into foreign language learning and teaching (pp. 51-70). Frankfurt am Main: Peter Lang.

Thorne, S.L. (2005). Epistemology, politics, and ethics in sociocultural theory. Modern Language Journal, 89, 393-409.

Toohey, K. (1995). From the ethnography of communication to critical ethnography in ESL teacher education. TESOL Quarterly, 29, 576-581.

Törrönen, J. (2002). Semiotic theory on qualitative interviewing using stimulus texts. Qualitative Research, 2, 343-362.

Ushakova, T.N. (1994). Inner speech and second language acquisition: An experimentaltheoretical approach. In J.P. Lantolf \& G. Appel (Eds.), Vygotskian approaches to second language research (pp. 135-156). Norwood, NJ: Ablex.

van Lier, L. (1996). Interaction in the language curriculum: Awareness, autonomy and authenticity. Harlow, UK: Longman.

van Lier, L. (2000). From input to affordance: Social-interactive learning from an ecological perspective. In J.P. Lantolf (Ed.), Sociocultural theory and second language learning (pp. 245259). Oxford, UK: Oxford University Press.

van Lier, L. (2004). The ecology and semiotics of language learning: A sociocultural perspective. Norwell, MA: Kluwer.

Vygotsky, L.S. (1978). Mind in society: The development of higher psychological processes. Cambridge, MA: Harvard University Press.

Wallace, M.J. (1998). Action research for language teachers. Cambridge, UK: Cambridge University Press.

Wartofsky, M.W. (1979). Models: Representation and the scientific understanding. Dordrecht, Netherlands: Reidel.

Washburn, G.N. (1994). Working in the ZPD: Fossilized and nonfossilized nonnative speakers. In J.P. Lantolf \& G. Appel (Eds.), Vygotskian approaches to second language research (pp. 6981). Norwood, NJ: Ablex.

Watson-Gegeo, K.A. (2004). Mind, language, and epistemology: Toward a language socialization paradigm for SLA. Modern Language Journal, 88, 331-350.

Wertsch, J.V. (1991). Voices of the mind: A sociocultural approach to mediated action. Cambridge, MA: Harvard University Press.

Willig, C. (2008). Introducing qualitative research in psychology: Adventures in theory and method (2nd ed.). Milton Keynes, UK: Open University Press.

Winter, R. (1989). Learning from experience: Principles and practice in action-research. London: Falmer.

Yost, D.S., Sentner, S.M., \& Forlenza-Bailey, A. (2000). An examination of the construct of critical reflection: Implications for teacher education programming in the 21st century. Journal of Teacher Education, 51, 39-49. 